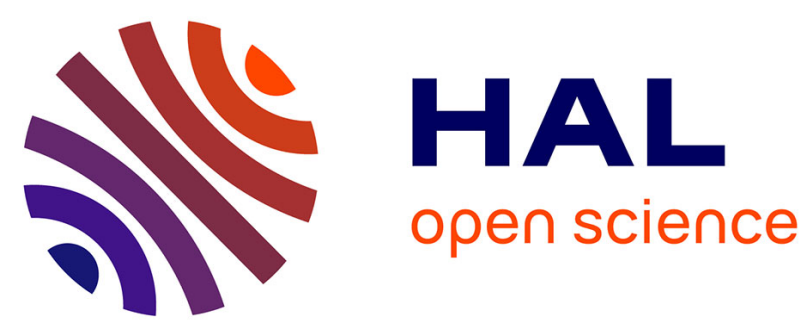

\title{
Effects of wind wave turbulence on the phytoplankton community composition in large, shallow Lake Taihu
} Jian Zhou, Boqiang Qin, Céline Casenave, Xiaoxia Han, Guijun Yang, Tingfeng Wu, Pan Wu, Jianrong Ma

\section{- To cite this version:}

Jian Zhou, Boqiang Qin, Céline Casenave, Xiaoxia Han, Guijun Yang, et al.. Effects of wind wave turbulence on the phytoplankton community composition in large, shallow Lake Taihu. Environmental Science and Pollution Research, 2015, 22 (16), pp.12737-12746. 10.1007/s11356-015-4535-2 . hal01150611

\section{HAL Id: hal-01150611 \\ https://hal.science/hal-01150611}

Submitted on 11 May 2015

HAL is a multi-disciplinary open access archive for the deposit and dissemination of scientific research documents, whether they are published or not. The documents may come from teaching and research institutions in France or abroad, or from public or private research centers.
L'archive ouverte pluridisciplinaire HAL, est destinée au dépôt et à la diffusion de documents scientifiques de niveau recherche, publiés ou non, émanant des établissements d'enseignement et de recherche français ou étrangers, des laboratoires publics ou privés. 


\title{
Effects of wind wave turbulence on the phytoplankton community composition in large, shallow Lake Taihu
}

Jian Zhou ${ }^{1,2}$, Boqiang Qin ${ }^{1 *}$, Céline Casenave ${ }^{3}$, Xiaoxia $\mathrm{Han}^{4}$, Guijun Yang ${ }^{5}$, Tingfeng $\mathrm{Wu}^{1}$, Pan $\mathrm{Wu}^{1,2}$, Jianrong $\mathrm{Ma}^{6}$

${ }^{1}$ State Key Laboratory of Lake Science and Environment, Nanjing Institute of Geography and Limnology, Chinese Academy of Sciences, 73 East Beijing Road, Nanjing 210008, P. R. China

${ }^{2}$ University of Chinese Academy of Sciences, Beijing 100049, P. R. China

${ }^{3}$ UMR INRA-SupAgro 0729 MISTEA (Mathematics, Informatics and Statistics for Environment \& Agronomy), 2 place Pierre Viala, 34060 Montpellier, France

${ }^{4}$ College of Resources and Environmental Sciences, Nanjing Agricultural University, Nanjing 210095, P. R. China

${ }^{5}$ School of Environmental and Civil Engineering, Jiangnan University, 1800 Lihu Avenue, Wuxi 214122, P. R. China

${ }^{6}$ Key Laboratory of Reservoir Aquatic Environment, Chongqing Institute of Green and Intelligent Technology, Chinese Academy of Sciences, Chongqing 400714, China

Corresponding Author: Prof. Boqiang Qin

Nanjing Institute of Geography and Limnology, Chinese Academy of Sciences, 73 East Beijing Road, Nanjing 210008, China

Tel: +86 025-86882192;

Fax: +86 025-57714759;

E-mail: qinbq@niglas.ac.cn

\begin{abstract}
Wind waves are responsible for some of the spatio-temporal gradients observed in the biotic and abiotic variables in large shallow lakes. However, their effects on the phytoplankton community composition are still largely unexplored especially in freshwater systems such as lakes. In this paper, using field observations and mesocosm bioassay experiments, we investigated the impact of turbulence generated by wind waves on the phytoplankton community composition (especially on harmful cyanobacteria) in Lake Taihu, a large, shallow eutrophic lake in China. The composition of the phytoplankton community varied with the intensity of wind waves in the different areas of the lake. During summer, when wind waves were strong in the central lake, diatoms and green algae seemed to dominate while harmful cyanobacteria dominated in the weakly influenced Meiliang Bay. Turbulence bioassays also showed that diatoms and green algae were favoured by turbulent mixing. The critical time for the shift of the phytoplankton community composition was approximately 10 days under turbulent conditions. However, short-term (6 days) turbulence is rather beneficial for the dominance of cyanobacteria. This study suggests that the duration of wind events and their associated hydrodynamics are key factors to understanding the temporal and spatial changes of phytoplankton communities.
\end{abstract}

Keywords: Wind waves · Turbulence · Phytoplankton community composition · Dominance · Cyanobacterial blooms

\section{Introduction}

The phytoplankton community is controlled not only by local environmental conditions but also by physical processes occurring on different temporal and spatial scales (Donaghay and Osborn 1997). Wind waves play an important role in water ecosystems, especially in large shallow lakes where some spatial and temporal phytoplankton patterns match the characteristic properties of wind-driven environments (Estrada and Berdalet 1997; Cardoso and Marques 2009). Other studies have shown that wind waves can influence 
the phytoplankton settling velocity (Ruiz et al. 2004), vertical and horizontal distribution (Cao et al. 2006; Moreno-Ostos et al. 2009; Wu et al. 2010) and formation of cyanobacterial blooms (Wu et al. 2013). In fact, wind waves induce several physical processes in large, shallow lakes, the most important of which are turbulence, turbidity, and the release of nutrients (Cardoso and Marques 2009). Turbulence has been shown to have some impacts on the phytoplankton community composition and can select for particular life-forms (Arin et al. 2002). For example, intense turbulent mixing has caused species replacements from dinoflagellates in oceans or cyanobacteria in lakes/rivers towards diatoms/green algae dominated communities (reviewed by Huisman et al. 2004). In shallow lakes, turbulence can control and, in some situations, govern the phytoplankton community (Cardoso and Marques 2009). This also explains why an increasing number of studies focusing on wind waves are being performed in large shallow lakes to further understand the spatial and/or temporal variations of phytoplankton communities (Carrick et al. 1993; Cao et al. 2006).

Lake Taihu (Taihu) is the third largest freshwater lake in China, which has an area of $2338 \mathrm{~km}^{2}$. It is a shallow, eutrophic lake with an average depth of $1.9 \mathrm{~m}$ and maximum depth of $2.6 \mathrm{~m}$, which is strongly influenced by wind waves (Qin et al. 2007). Taihu is also a key drinking water source for 40 million people (Xu et al. 2010). However, to the despair of the inhabitants around the lake, dense surface harmful cyanobacterial blooms (CyanoHABs) of the cyanobacterium Microcystis have appeared in the northern (Meiliang Bay) and western regions of the lake every summer since the mid-1980s (Qin et al. 2010).

The effects of wind waves on the nutrient availability (Qin et al. 2007; Zhu et al. 2007) and phytoplankton distributions (Cao et al. 2006; Wu et al. 2010) have been well studied in Lake Taihu. However, our understanding of the relationships between wind waves and the phytoplankton community composition in the lake is still limited. Wu et al. (2013) previously showed that cyanobacterial blooms in Taihu form and expand in the absence or presence of soft wind waves. However, the effects of intense wind waves on the phytoplankton community composition, and dynamics of harmful algal blooms (HABs) have not yet been explored.

In this paper, high-frequency observation of meteorological parameters and corresponding monthly phytoplankton and environmental data, coupled with turbulence bioassay experiments were conducted to characterise the impact of the wind wave turbulence on phytoplankton communities in Taihu. Specifically, this study aims: 1) to observe the monthly variation of phytoplankton community composition in Meiliang Bay and the central lake, which are two areas of the lake with different hydrodynamic conditions; 2) to identify the effects of wind wave turbulence on phytoplankton communities in bioassay experiments; and 3) to determine if turbulence can be used as a method to mitigate or prevent the formation of CyanoHABs in Taihu.

\section{Materials and Methods \\ Field study}

Study site

Two stations in Taihu were selected for sampling (Fig. 1): one in Meiliang Bay (Sta. 1) and the other in the central lake (Sta. 2). The two stations were chosen for their varying physico-chemical characteristics, extent of influence of wind waves and recorded occurrences of CyanoHABs (Qin et al. 2007), providing good contrast for the study (Table 1). To understand potential shifts in the phytoplankton community and their underlying factors, monthly physical, chemical and biological data were collected in Station 1 and 2 for the entirety of 2013 by the Taihu Laboratory for Lake Ecosystem Research (TLLER), Nanjing Institute of Geography and Limnology, Chinese Academy of Sciences (Fig. 1). Additionally, a Sontek Argonaut XR (Sontek/YSI, San Diego, California, USA) was used to measure the wave height near Sta. 1 (Fig. 1), which was unavailable in the central lake. As a proxy, the wind speed was automatically measured in a monitoring station in Sta. 2. Then, the SWAN (simulating wave nearshore) model was used to transform the wind speed into a wave height ( $\mathrm{Li}$ et al. 2008). Half-hourly datasets in the two stations were analysed to characterise the turbulence of wind waves in 2013. 


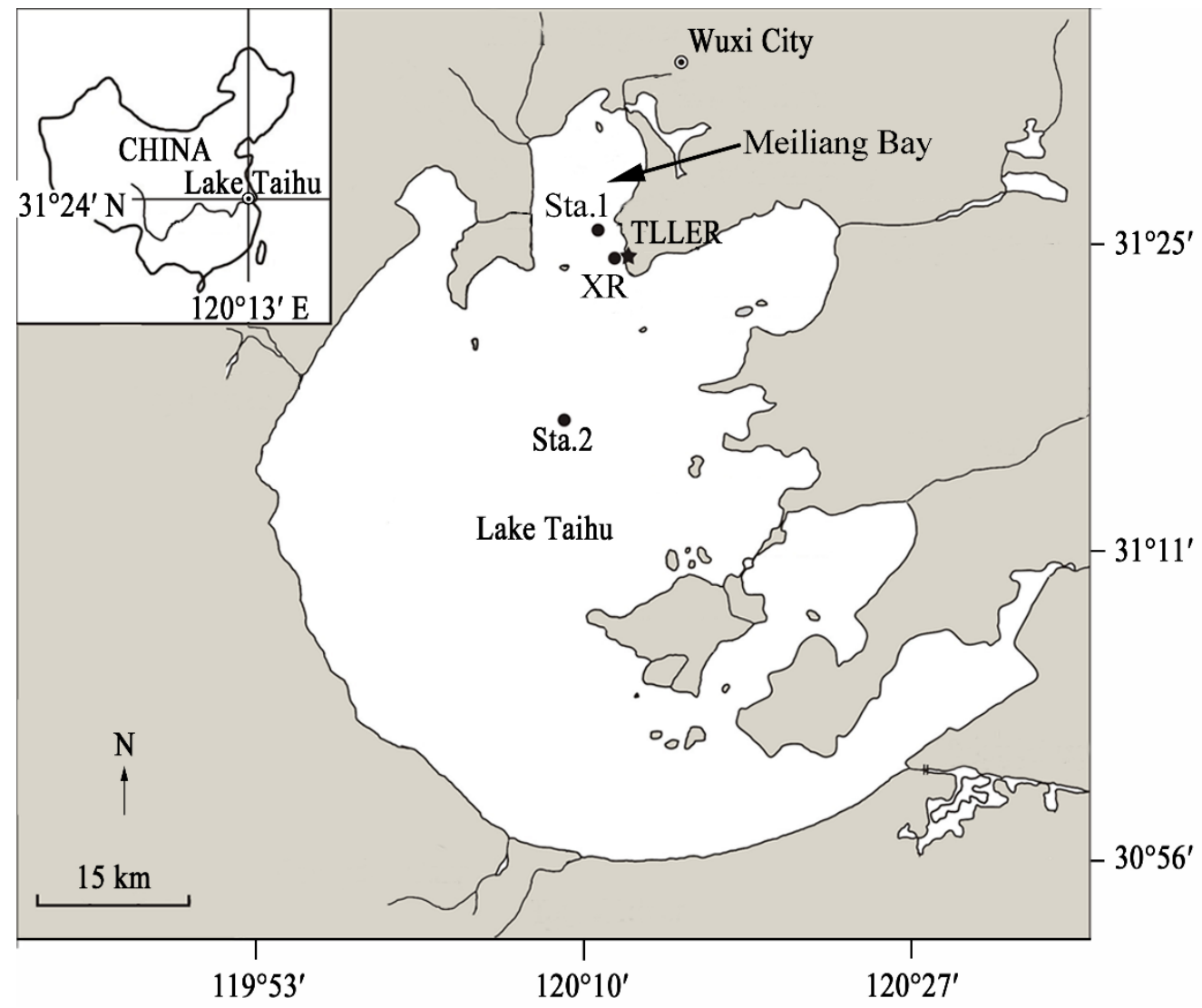

Fig. 1 Lake Taihu: Sta.1 and Sta. 2 are the locations at which the phytoplankton samples, and high-frequency wave height for Sta.2, were routinely collected during 2013. XR shows the location of the wave height monitoring and TLLER (Laboratory for Lake Ecosystem Research) shows the location at which the turbulence bioassays were incubated.

Table 1 Mean and standard deviation of the physical and chemical measurements in Meiliang Bay and the central lake during 2013. WT, water temperature; DO, dissolved oxygen; EC, electrical conductivity; WH, wave height; $\mathrm{TN}$, total nitrogen; TDN, total dissolved nitrogen; $\mathrm{NO}_{3}^{-}$, nitrate; $\mathrm{NO}_{2}^{-}$, nitrite; $\mathrm{NH}_{4}{ }^{+}$, ammonium; TP, total phosphorus; TDP, total dissolved phosphorus; and SRP, soluble reactive phosphorus. Data were obtained from TLLER.

\begin{tabular}{|c|c|c|c|}
\hline & Parameter & Meiliang Bay & Cental lake \\
\hline \multirow[t]{5}{*}{ Physical } & $\mathrm{WT}\left({ }^{\circ} \mathrm{C}\right)$ & $18.101 \pm 9.322$ & $17.564 \pm 9.062$ \\
\hline & $\mathrm{DO}\left(\mathrm{mg} \mathrm{L}^{-1}\right)$ & $9.589 \pm 1.726$ & $8.963 \pm 1.503$ \\
\hline & $\mathrm{pH}$ & $8.223 \pm 0.416$ & $8.223 \pm 0.244$ \\
\hline & $\mathrm{EC}\left(\mu \mathrm{S} \mathrm{cm}^{-1}\right)$ & $482.5 \pm 82.228$ & $477.5 \pm 94.062$ \\
\hline & WH (cm) & $1.104 \pm 2.099$ & $11.818 \pm 5.813$ \\
\hline \multirow[t]{8}{*}{ Chemical } & $\mathrm{TN}\left(\mathrm{mg} \mathrm{L}^{-1}\right)$ & $2.653 \pm 0.906$ & $2.356 \pm 1.518$ \\
\hline & $\mathrm{TDN}\left(\mathrm{mg} \mathrm{L}^{-1}\right)$ & $1.540 \pm 1.111$ & $1.837 \pm 1.450$ \\
\hline & $\mathrm{NO}_{3}^{-}\left(\mathrm{mg} \mathrm{L}^{-1}\right)$ & $0.540 \pm 0.513$ & $0.820 \pm 0.837$ \\
\hline & $\mathrm{NO}_{2}^{-}\left(\mathrm{mg} \mathrm{L}^{-1}\right)$ & $0.019 \pm 0.018$ & $0.015 \pm 0.028$ \\
\hline & $\mathrm{NH}_{4}^{+}\left(\mathrm{mg} \mathrm{L}^{-1}\right)$ & $0.380 \pm 0.121$ & $0.391 \pm 0.166$ \\
\hline & $\mathrm{TP}\left(\mathrm{mg} \mathrm{L}^{-1}\right)$ & $0.148 \pm 0.097$ & $0.094 \pm 0.032$ \\
\hline & $\mathrm{TDP}\left(\mathrm{mg} \mathrm{L}^{-1}\right)$ & $0.038 \pm 0.017$ & $0.038 \pm 0.021$ \\
\hline & $\mathrm{SRP}\left(\mathrm{mg} \mathrm{L}^{-1}\right)$ & $0.018 \pm 0.014$ & $0.022 \pm 0.015$ \\
\hline
\end{tabular}

Bold values indicate that there is a significant difference between Meiliang Bay and the central lake, which was determined by ANOVA. 
Physical, chemical, and biological conditions

Physico-chemical and biological parameters were measured in the middle of each month for the entire-duration of the study. Physical parameters, including the water temperature (WT), dissolved oxygen (DO), $\mathrm{pH}$, and electrical conductivity (EC), were measured with Yellow Springs Instruments (YSI, San Diego, California, USA) 6600 multi-sensor sonde.

Water samples were analysed for nutrients such as total nitrogen (TN), total dissolved nitrogen (TDN), dissolved inorganic nitrogen (DIN; ammonium $\left(\mathrm{NH}_{4}^{+}\right)+$nitrate $\left(\mathrm{NO}_{3}{ }^{-}\right)+$nitrite $\left(\mathrm{NO}_{2}{ }^{-}\right)$), total phosphorus (TP), total dissolved phosphorus (TDP), and soluble reactive phosphorus (SRP), according to the methods described by $\mathrm{Xu}$ et al. (2010). The particulate nitrogen (PN) was obtained by subtracting the TDN from the TN and particulate phosphorus (PP) as the difference between the TDP from the TP.

Phytoplankton samples were fixed with Lugol's iodine solution ( $2 \%$ final conc.) and allowed to settle for $48 \mathrm{~h}$ prior to counting with a Sedgwick-Rafter counting chamber under microscopic magnifications of 200-400×. Phytoplankton species were identified following the taxonomic classification of Hu et al. (1980). Algal biovolumes were calculated from the cell numbers and cell size measurements. Conversion to biomass assumes that $1 \mathrm{~mm}^{3}$ of the volume is equivalent to $1 \mathrm{mg}$ of fresh-weight biomass (Xu et al. 2010).

\section{Turbulence bioassay experiments}

\section{Experimental setup}

The experimental setup is consisted of a tank, energy dissipation plate, and frequency conversion wave-maker pump (Fig. 2). The tank and the energy dissipation plate consist of $8 \mathrm{~mm}$ thick Plexiglas; their structure and size are shown in Fig. 2. Each tank has a maximal capacity of 126 L. To reduce the rebound of waves, considering costs and feasibility, the tanks were designed with a sloping side with a slope being of 5:1 (Fig. 2a) where an energy dissipation plate was also fixed (Fig. 2b). The wave-maker pumps (Fig. 2c) are fixed on the opposite side of the tanks. A total of 6 units of this experimental setup were built.
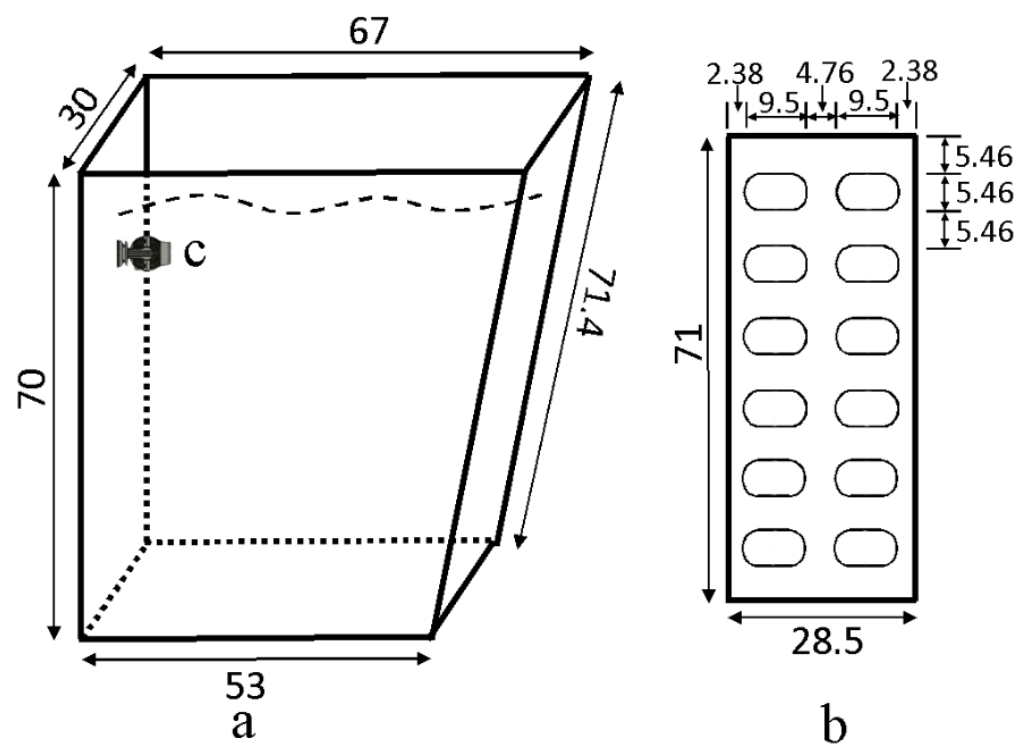

Fig. 2 Diagram of a tank (a), an energy dissipation plate (b), and a wave-maker pump (c). All dimensions are given in $\mathrm{cm}$.

\section{Experimental design}

To minimise the "bottle effects", the experiment was only conducted for a total of 15 days. The bioassay experiments were performed from the $7^{\text {th }}$ to the $22^{\text {nd }}$ of July 2014 at TLLER on the shores of Taihu, in Wuxi. Chemical contamination released from the material (Plexiglas) was avoided by immersing the tanks in water for 15 days before the start of the experiments. Each pre-cleaned tank was filled with 96 
litres of lake water pumped from $0.2 \mathrm{~m}$ subsurface of the water column. Finally, all tanks were floated and fixed in an outside artificial pond $(10 \times 10 \times 2 \mathrm{~m})$ which was filled with lake water and dug $1 \mathrm{~m}$ into the ground. This mimics natural conditions as closely as possible. To prevent algal adhesion, the inside walls of each tank (except the bottom) were gently brushed at 6:30 PM every day.

Two treatments were tested, one $(\mathrm{T})$ where a pump generated turbulence was applied and the other (C) was calm (no artificial turbulence was induced), which also served as the control. Both treatments were conducted in triplicate.

\section{Turbulence generation}

To achieve hydrodynamic turbulence that was as similar as possible to the one induced by natural wind waves, we used a submerged wave-maker pump (WP, Jebao, China), which was fixed under the water surface with some magnets and was also tested and demonstrated in previous studies (Clarke et al. 2005; Pekcan-Hekim et al. 2013; Härkönen et al. 2014).

The pump frequency was set to $1 \mathrm{~Hz}$ and the turbulence generated was monitored and measured by an acoustic Doppler velocimeter (ADV) (10 MHz ADVField; Sontek/YSI, San Diego, California, USA). The turbulence intensity was measured from the middle of the tank with a $25 \mathrm{~Hz}$ measurement for a period of 2 min. Measurements were performed after the turbulent motion in the tank had reached a steady state (after 6-7 min).

To define the characteristic speed of the turbulence, the root mean square (RMS) velocity $\left(\mathrm{cm} \mathrm{s}^{-1}\right)$ was calculated using the following formula

where

$$
R M S=\sqrt{\mu_{R M S_{x}}{ }^{2}+\mu_{R M S_{y}}{ }^{2}+\mu_{R M S_{z}}{ }^{2}}
$$

$$
\mu_{R M S_{x}}=\sqrt{\frac{\sum \mu_{x}^{2}-\left(\sum \mu_{x}\right)^{2} / n}{n-1}}
$$

is the fluctuation of the flow for Cartesian vector $x$ (which is similarly calculated for the $y$ and $z$ vectors) and $n$ is the number of samples per measurement. The RMS velocities were expressed as averages for the whole tank. The energy dissipation rate $\left(\mathrm{m}^{2} \mathrm{~s}^{-3}\right)$, which describes the rate at which the turbulent energy decays over time, was deduced from the RMS velocity $\left(\mathrm{m} \mathrm{s}^{-1}\right.$ ) with the following formula (Sanford 1997):

$$
\varepsilon=A_{1} \frac{R M S^{3}}{l}
$$

where $A_{1}$ is an dimensional constant of order 1 (Kundu and Cohen 2010), and $l$ is the water depth (m) describing the size of the largest vortices.

The Reynolds number ( $R e$, the ratio of inertial forces to viscous forces) for a given turbulence level was calculated with the following formula (Peters and Redondo, 1997):

$$
R e=\frac{R M S l}{v}
$$

where $l$ is the water depth $(\mathrm{m})$ and $v$ is the kinematic viscosity for water $\left(8.5 \times 10^{-7} \mathrm{~m}^{2} \mathrm{~s}^{-1}\right)$.

The RMS velocity used in the experiments was $2.532 \mathrm{~cm} \mathrm{~s}^{-1}$, and the dissipation rate $(\varepsilon)$ and Reynolds number $(R e)$ corresponding to the turbulent velocity were $2.951 \times 10^{-5} \mathrm{~m}^{2} \mathrm{~s}^{-3}$ and 16384 , respectively. The hydrodynamic condition in Taihu was also measured in Sta. 1. The dissipation rate in Taihu varied between $6.014 \times 10^{-8}$ and $2.389 \times 10^{-4} \mathrm{~m}^{2} \mathrm{~s}^{-3}$, suggesting that the turbulence level used in our bioassay experiment was commonly found in Taihu.

\section{Measurements}

Physical and chemical parameters were measured every day from day 0 until day 9, and at days 12 and 15, between 7:00 and 8:00 in the morning. Biological parameters were measured starting at day 0 and every three days after that until day 15. First, physical parameters were measured at each tank. Then, chemical and biological samples were collected using a tube sampler, collecting 0.45 or $0.75 \mathrm{~L}$ water 
samples from each setup. The same methods of measurement and/or calculation of the physico-chemical and biological parameters were applied to both field observations and bioassay experiments.

The chlorophyll $a(\mathrm{Chl} a$ ) concentrations were measured by the spectrophotometric method (Pápista et al. 2002). Samples were first filtered through GF/F filters, frozen at $-20{ }^{\circ} \mathrm{C}$ and pigments were extracted with $90 \%$ hot acetone.

The dominant species were determined by calculating the Berger-Parker Index (BP) which is simply the proportion of the most abundance species, $\mathrm{BP}=\max \left(B_{\mathrm{i}}\right)$, where $B_{\mathrm{i}}$ is the relative biomass of the $\mathrm{i}^{\text {th }}$ species (Berger and Parker, 1970).

\section{Statistical analysis}

Significant differences between Meiliang Bay and the central lake and between the turbulence treatment and control were determined by one-way analysis of variance (ANOVA). Post-hoc multiple comparisons of treatment means were performed by Tukey's least significant difference method and the standard deviation in the variations of the triplicates was calculated. Statistical analysis was performed in SPSS 22.0 statistical package, and the level of significance used was $P<0.05$ for all tests.

\section{Results}

\section{Dynamics of the phytoplankton community composition}

The physical and chemical conditions (except for the wave height) in Meiliang Bay and the central lake generally did not differ significantly in 2013 (Table 1, $P>0.05$ ). However, the wave height varied greatly in the two stations. For example, in Sta. 1, the wave height ranged from 0.2 to $32.4 \mathrm{~cm}$ in 2013 which varied seasonally; it was larger in winter and spring, and smaller in the summer and early autumn (Fig. 3a). In particular, summer had an average wave height of only $0.49 \mathrm{~cm}$, which was mostly associated with waves below $1 \mathrm{~cm}$ that had a frequency of 94.91\% (Fig. 4a). In Sta. 2, on the other hand, wind disturbance was always present resulting in waves with heights ranging from 6.34 to $37.44 \mathrm{~cm}$ (Fig. 3b). While in summer, the average wave height was $12.30 \mathrm{~cm}$ with most waves higher than $6 \mathrm{~cm}$ accounting for $87.01 \%$ of the total number of waves that occurred (Fig. $4 \mathrm{~b}$ ).

Relative biomass $(B)$ of dominant phytoplankton taxa also varied with the season in both sampling stations. In Sta.1, the $B$ of Cyanophyta (cyanobacteria) was above 0.7 in summer and autumn, while the $B$ of Bacillariophyta (diatoms) and Chlorophyta (green algae) were below 0.2 (Fig. 3a). In Sta.2, the average $P$ of cyanobacteria and diatoms/green algae in summer were 0.39 and 0.49 , respectively. Interestingly, diatoms and green algae seem to be the dominant phyla during summer at the central lake (Fig. $3 \mathrm{~b}$ ), and there were significant differences in $B$ between Sta.1 and Sta.2 $(P<0.05)$. In the succeeding months, species of Cyanophyta replaced the other groups especially from late autumn to winter in Sta. 2 (Fig. 3).

\section{Physico-chemical and biological observations in bioassay experiments}

The measured environmental correlates (physical, chemical and biological) from this study are presented in Table 2. The water temperature ranged from 25.68 to $30.21^{\circ} \mathrm{C}$ with $\mathrm{DO}$ and $\mathrm{pH}$ higher in $\mathrm{C}$ than T during the experiments. Also, the average concentrations of the total and particulate nutrients (TN, $\mathrm{PN}, \mathrm{TP}$, and PP) varied between the treatments. For example, the average TN in C and T were $1.59 \pm 0.22$ and $1.85 \pm 0.09 \mathrm{mg} \mathrm{L}^{-1}(P<0.05)$, respectively. There was also a significant difference for TP with $\mathrm{C}$ $\left(0.049 \pm 0.022 \mathrm{mg} \mathrm{L}^{-1}\right)$, which was lower than $\mathrm{T}\left(0.061 \pm 0.016 \mathrm{mg} \mathrm{L}^{-1}\right)(P<0.05)$. The same was also true for the concentrations of different nitrogen (TDN and DIN) and phosphorus species (TDP and SRP). Moreover, Chl $a$ concentration was significantly higher in T than $\mathrm{C}(P<0.05)$. 


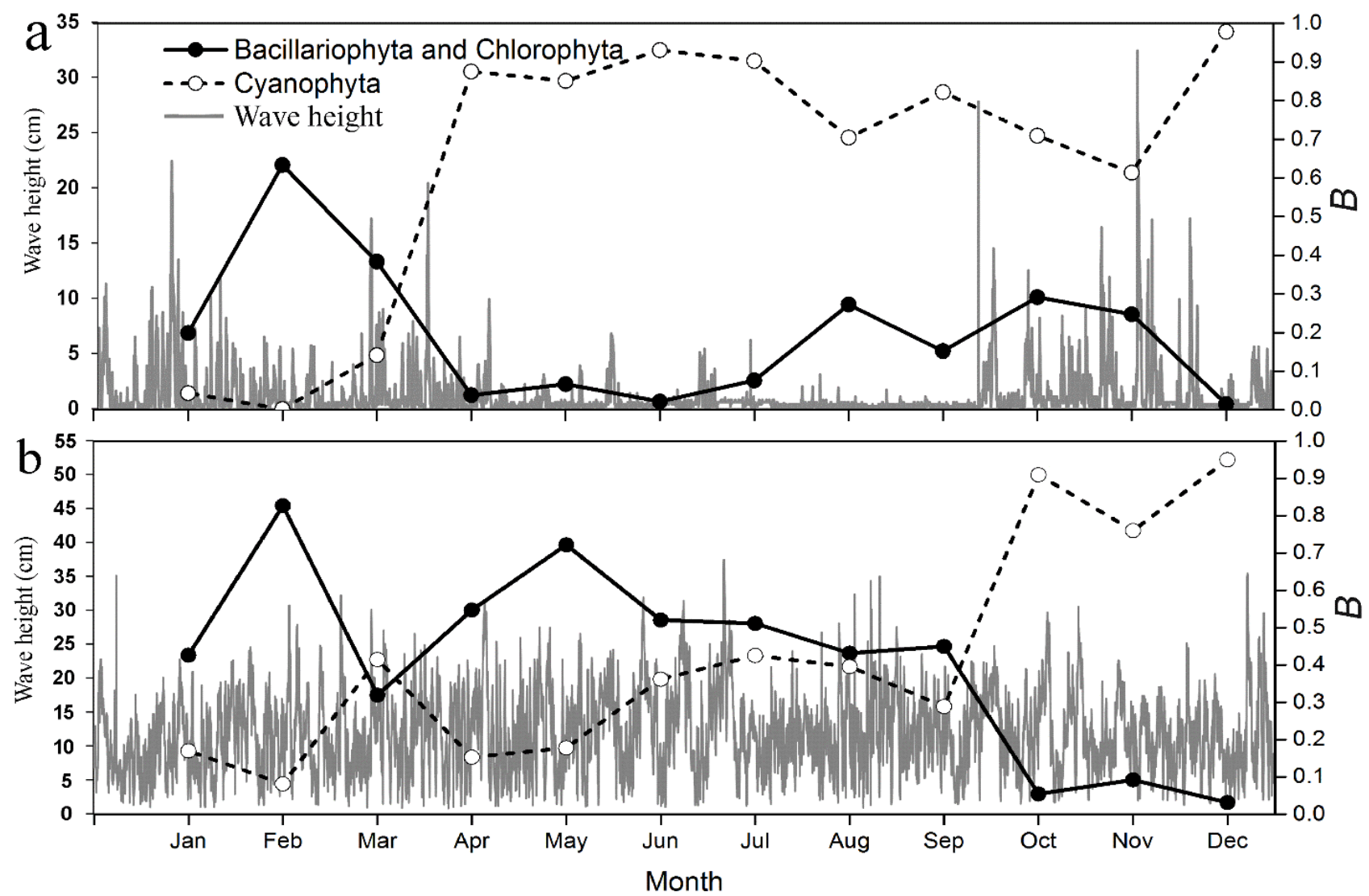

Fig. 3 The half-hourly variation of the wave height and B of Cyanophyta and Bacillariophyta/Chlorophyta in Sta.1 (a) and Sta.2 (b) during 2013. Data were obtained from TLLER.
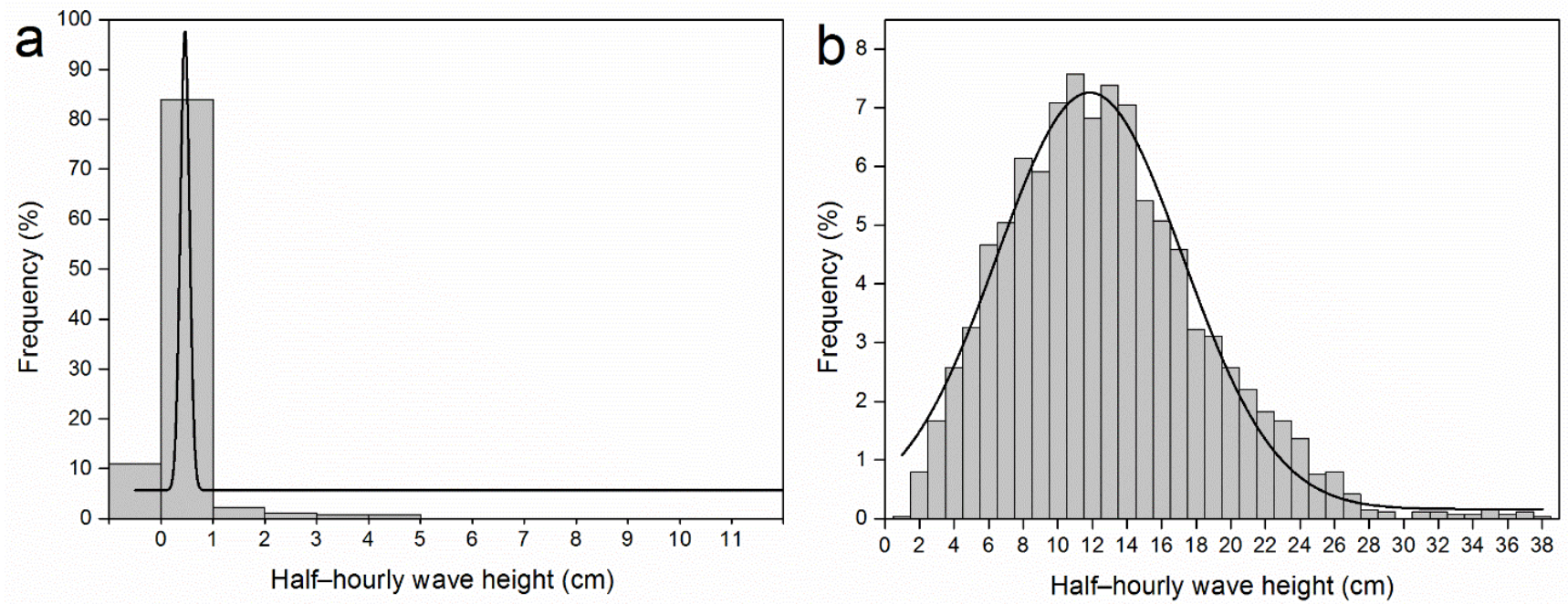

Fig. 4 Frequency histograms of the wave height for Sta.1 (a) and Sta.2 (b) in the summer of 2013. The line corresponds to the fitted Weibull frequency distributions that were obtained using the maximum likelihood method. 
Table 2 Mean and standard deviation of the physical, chemical and biological measurements with control (C) and turbulence treatment (T) during the experiments. WT, water temperature; DO, dissolved oxygen; TN, total nitrogen; PN, particulate nitrogen; TDN, total dissolved nitrogen; DIN, dissolved inorganic nitrogen; TP, total phosphorus; PP, particulate phosphorus; TDP, total dissolved phosphorus; and SRP, soluble reactive phosphorus.

\begin{tabular}{cccc}
\hline & Parameter & $\mathrm{C}$ & $\mathrm{T}$ \\
\hline Physical & $\mathrm{WT}\left({ }^{\circ} \mathrm{C}\right)$ & $27.801 \pm 1.412$ & $27.791 \pm 1.411$ \\
& $\mathrm{DO}\left(\mathrm{mg} \mathrm{L}^{-1}\right)$ & $8.593 \pm 1.158$ & $7.673 \pm 0.414$ \\
Chemical & $\mathrm{pH}$ & $8.737 \pm 0.309$ & $8.543 \pm 0.241$ \\
& $\mathrm{TN}\left(\mathrm{mg} \mathrm{L}^{-1}\right)$ & $1.586 \pm 0.217$ & $1.849 \pm 0.091$ \\
& $\mathrm{PN}\left(\mathrm{mg} \mathrm{L}^{-1}\right)$ & $0.489 \pm 0.068$ & $0.822 \pm 0.157$ \\
& $\mathrm{TDN}\left(\mathrm{mg} \mathrm{L}^{-1}\right)$ & $1.097 \pm 0.190$ & $1.027 \pm 0.202$ \\
& $\mathrm{DIN}\left(\mathrm{mg} \mathrm{L}^{-1}\right)$ & $0.684 \pm 0.197$ & $0.638 \pm 0.224$ \\
& $\mathrm{TP}\left(\mathrm{mg} \mathrm{L}^{-1}\right)$ & $0.049 \pm 0.022$ & $0.061 \pm 0.016$ \\
& $\mathrm{PP}\left(\mathrm{mg} \mathrm{L}^{-1}\right)$ & $0.038 \pm 0.020$ & $0.048 \pm 0.016$ \\
& $\mathrm{TDP}\left(\mathrm{mg} \mathrm{L}^{-1}\right)$ & $0.011 \pm 0.007$ & $0.013 \pm 0.006$ \\
& $\mathrm{SRP}\left(\mathrm{mg} \mathrm{L}^{-1}\right)$ & $0.0047 \pm 0.0045$ & $0.0053 \pm 0.0048$ \\
& $\mathrm{Chl} a\left(\mu \mathrm{L} \mathrm{L}^{-1}\right)$ & $19.425 \pm 6.061$ & $32.308 \pm 8.362$ \\
\hline
\end{tabular}

\section{Impacts of turbulence on phytoplankton communities}

Initially, the phytoplankton community (relative biomass) in the tanks consisted of Cyanophyta (38.03\%), Bacillariophyta (33.82\%), Chlorophyta (15.50\%), and other algae (12.66\%). Cyanophyta increased to a maximum relative biomass of $84.97 \%$ at day 9 in C, while it only reached $78.58 \%$ at day 6 in T (Fig. 5) and these were significantly different $(P<0.05)$. In addition, Cyanophyta remained the most dominant phyla for the entire duration of the experiments in $C$, while it decreased quickly as Bacillariophyta increased in abundance after approximately 10 days in $\mathrm{T}$ (Fig. 5). At the end of the experiments, the proportions of Bacillariophyta in C (20.23\%) were much lower than T (78.06\%) (Fig. 5).

Fragilaria spp. and Microcystis spp. were the two dominant species during the experiments with $B$ 's of 0.02 and 0.35 at the start of the experiments. However, Microcystis spp. (Cyanophyta) increased only until day 6 in $\mathrm{T}$ and day 9 in $\mathrm{C}$, and it decreased afterwards in both treatments (Fig. 6). A significant difference in the proportions of communities in between the treatments was observed just after 6 days $(P<$ 0.05). In contrast, Fragilaria spp. rapidly increased in T after day 6 (Fig. 6b). At the end of the experiment, the $B$ of Microcystis spp. and Fragilaria spp. were 0.67 and 0.16 in $\mathrm{C}$ and 0.19 and 0.77 in T. Microcystis spp. was always the dominant species in C (Fig. 6a), whereas in T, Fragilaria spp. became the dominant species and replace Microcystis spp. after approximately 10 days (Fig. 6b).
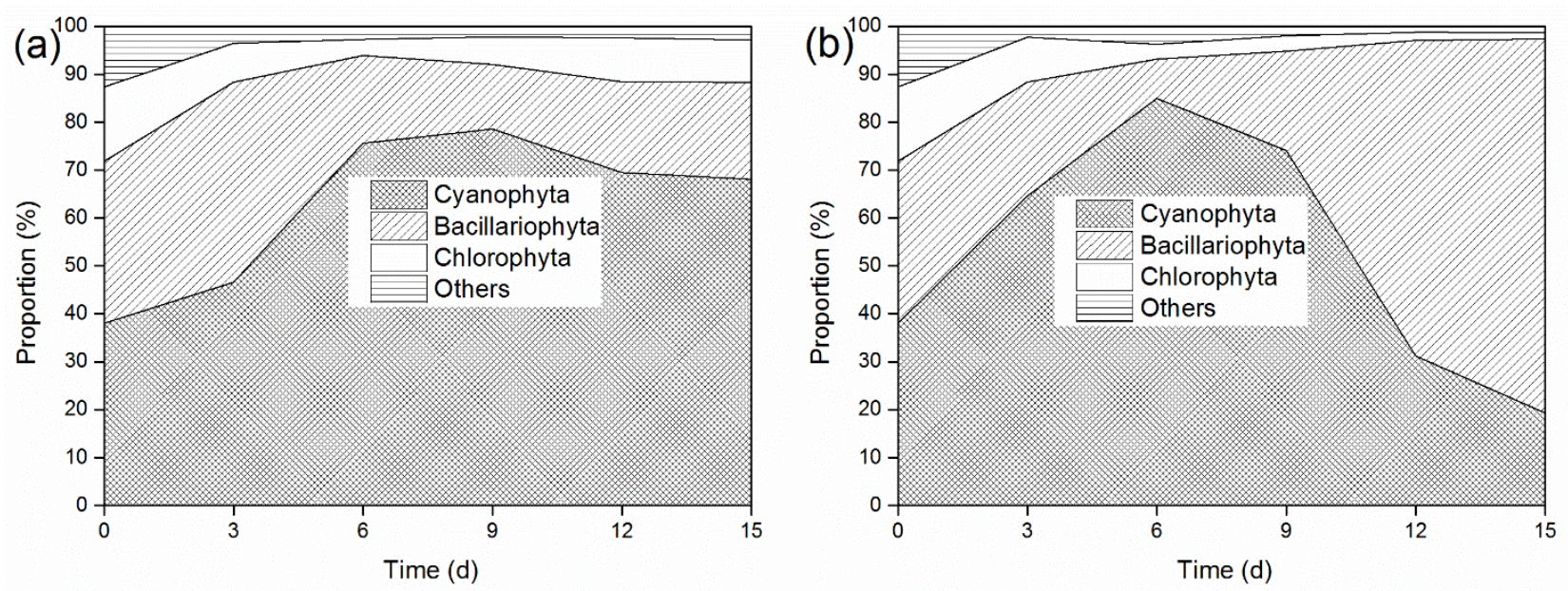

Fig. 5 The proportional contributions of Cyanophyta, Bacillariophyta, Chlorophyta, and others to the total biomass in control (a) and turbulence treatment (b) during the experiments. 

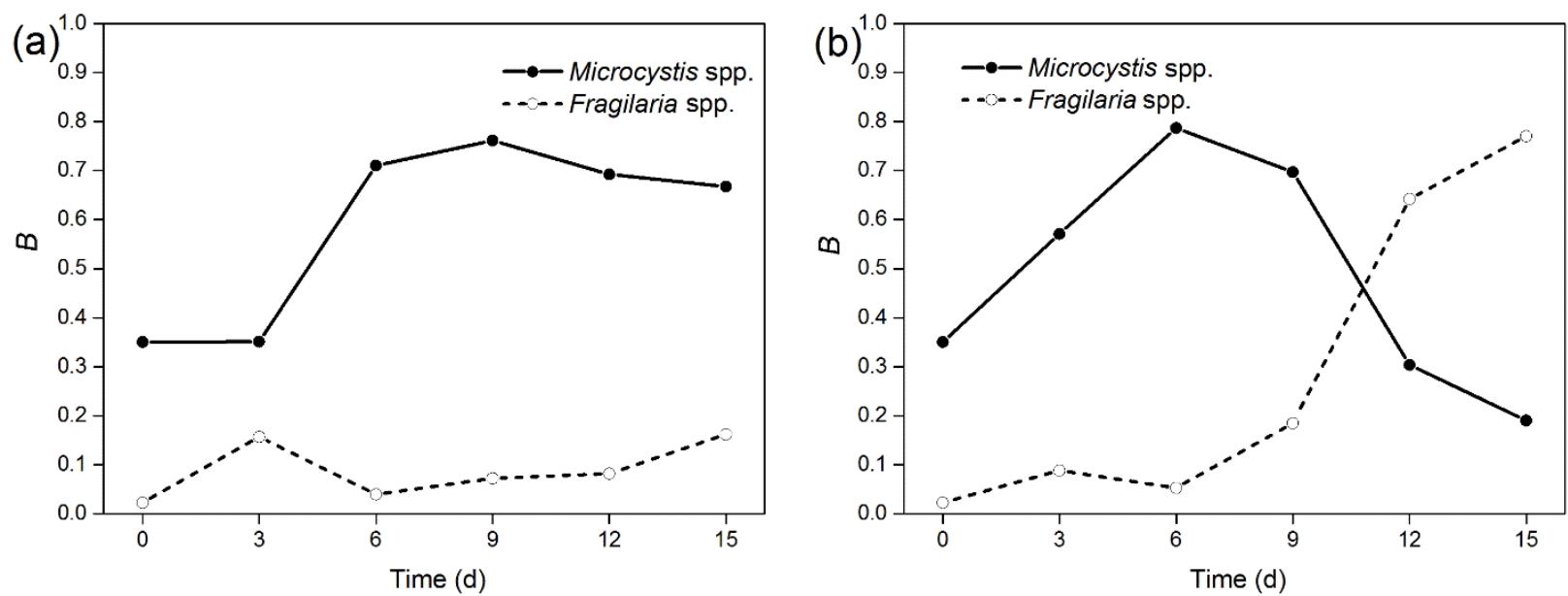

Fig. 6 The $B$ variation of Microcystis spp. and Fragilaria spp. with control (a) and turbulence treatment (b) during the experiments.

\section{Discussion}

\section{Impact of wind waves on phytoplankton in Meiliang Bay and the central lake}

Hydrodynamic conditions were significantly different between Meiliang Bay and the central lake (Table 1). It has been shown that turbulent mixing induced by wind, strongly affects the spatial distribution of the buoyant and potentially toxic Microcystis spp. (Wu et al. 2010; Wu et al. 2013). Some efforts have been made to determine the threshold wind speed that prevented algal blooms (Wong et al. 2007; Hunter et al. 2008). In Lake Taihu (Taihu), to inhibit surface bloom formation, a minimum wind speed of $3.0 \mathrm{~m} \mathrm{~s}^{-1}$ and a wave height of approximately $6.2 \mathrm{~cm}$ are required (Wu et al. 2010; Cao et al. 2006). When conditions are below these specific requirements, Microcystis mainly migrates horizontally which then facilitates the formation of surface blooms, suggesting that soft wind is beneficial to algal aggregation and HABs formation. On the contrary, when the wind speed and wave height are larger than the threshold values, water mixing causes vertical transport of the phytoplankton and away from the euphotic zone inhibiting photosynthetic activities. Wu et al. (2013) showed that when wind speed increases to higher than $6 \mathrm{~m} \mathrm{~s}^{-1}$, the entire water column in Taihu is overturned (mixed from the bottom to the top).

In our study, the average wave height in Meiliang Bay was only $0.49 \mathrm{~cm}$ in summer. The low wind activity in the area during the said period allowed the buoyant and toxic cyanobacterium Microcystis to aggregate in the water surface, causing a shade-effect on the underlying phytoplankton communities (e.g., diatoms and green algae, Huisman et al. 2004). This advantage in the competition for light, coupled with low physical disturbance (i.e., wind mixing), caused Microcystis to become the most severe CyanoHABs in Meiliang Bay (Fig. 3a). By contrast, the impacts of strong wind mixing could have been more pronounced in the central lake, as indicated by the high frequency (87.01\%) of waves with heights above 6 $\mathrm{cm}$ in the same period (Fig. 4b). As a consequence, mixing induced shifts in the phytoplankton community, favouring dominance of diatoms and green algae; therefore, there were no severe CyanoHABs at the central lake during summer.

\section{Phytoplankton community composition in turbulent environments}

Changes in the intensity and extent of turbulence in natural waters bodies, such as those driven by climate change, may induce major shifts in the species composition of phytoplankton communities (Huisman et al. 2004). Furthermore, the turbulence from wind waves could select for particular life forms within the microbial communities such as phytoplankton (Arin et al. 2002). Unfortunately, few studies have focused on this phenomenon in lakes. In the field, the impacts of turbulence cannot be separated from other physical processes, which makes the interpretation of the field datasets more complex. To evaluate the impact of wind wave turbulence on the biological communities, bioassay experiments were performed. 
The dissipation rate $(\varepsilon)$ used in these bioassay experiments is commonly found in Taihu and other large shallow lakes (Lake Blaton, Netherland, G.-Tóth et al. 2011).

Turbulence mixing can shift the competitive balance in phytoplankton species. Previous studies showed that the dominance of diatoms and green algae in turbulent environments is associated with a number of variables. First, turbulence affects the competition for nutrients. Enhancement of nutrient uptake in turbulent water is more important for larger cells (diatoms and green algae) than for small ones because of their volume:ratio advantage (Microcystis) (Prairie et al. 2012; Barton et al. 2014). Second, turbulence affects the competition for light. Gas-vacuolated cyanobacteria can take advantage in calm waters by the increasing nutrient flux and light absorption through vertical migratory behaviour (Oliver 1994). On the other hand, non-motile diatoms and green algae are better adapted to fluctuating light conditions experienced in turbulent environment than buoyant cyanobacteria (Huisman et al. 2004). Third, sedimentation losses of non-motile diatoms and green algae due to their size and weight is decreased by resuspension through mixing. Finally, turbulence impacts the feeding rate of heterotrophic or mixotrophic plankton (e.g. zooplankton, microzooplankton). Compared to cyanobacteria, chlorophytes and diatoms are generally considered as good-quality foods for herbivorous zooplankton (Gulati and DeMott 1997; Wilson et al. 2006). However, mixing in general increases the chances of encounter between the prey and predator, but also reduces capture rates (reviewed by Pécseli et al. 2014). Therefore, the low capture rates of diatoms and green algae by predators in turbulent environments contribute to factors that allow the dominance of diatoms and green algae. Consequently, hydrodynamics turbulence would favour the dominance of diatoms and green algae, which are, generally, better adapted to turbulent environments than buoyant cyanobacteria. In addition, depending on their habitat-dependent physiological characteristics, the coupling of hydrodynamics and nutrient concentrations could determine the dominant diatom species (Romero et al. 2012; Wang et al. 2012). The results reported in this paper are consistent with previous field studies and theories proposed to explain shifts in the competitive balance between buoyant and sinking phytoplankton species in freshwater ecosystems (Huisman et al. 2004; Cardoso and Marques 2009).

Our work also aimed to examine the critical time for a shift in the phytoplankton community composition under the turbulent environment in Taihu. Previous studies have analysed the threshold wind influence in terms of the magnitude (Wu et al. 2010; Cao et al. 2006), but an understanding of the time length of the episodes is still lacking. To have significant and quick changes in the phytoplankton community, experiments are generally conducted under constant, relatively high turbulence conditions, lasting for several days (Peters and Marrasé 2000). However, if the aim is to reproduce the turbulence found in natural conditions, such as that of the lake, time should be considered an important factor. Although it is true that relatively high turbulence levels, such as those used in many laboratory experiments are common in the lake, organisms may rarely experience them for a long time in nature (Guadayol and Peters 2006). In our study, the critical time for a shift in phytoplankton community composition was approximately 10 days (Fig. 5, 6). However, short-term turbulence would be rather beneficial to Microcystis and harmful algae blooms, which is consistent with recent field studies that shortterm tropical cyclones (intense wind wave) stimulate buoyant Microcystis spp. algal blooms in Taihu (Zhu et al. 2014). The relationship, however, between the magnitude and persistence of turbulence (time) in Taihu is not clear and still requires further study.

Finally, we observed that that the harmful Cyanophyta (almost Microcystis) was the dominant phylum in Taihu during late autumn and winter, even in the central area whereas the wind forcing hasn't change (Figure 3). During late autumn and winter, when the water is colder, the harmful Cyanophyta (mainly Microcystis) was the dominant taxa in Taihu, even in the central area where wind forcing was strong (Figure 3). Microcystis can persist better than other algae in cold waters, although their growth rate and photosynthetic activity remain low. This is supported by simulation experiments and field observations, all of which suggest that Microcystis in Taihu can to adapt to low temperatures and even form blooms in the winter (unpublished data). Persistent blooms of Microcystis aeruginosa has also been reported in Hartbeesport Dam, South Africa during the winter period (Zohary 1985). 


\section{Physico-chemical conditions and phytoplankton biomass in the bioassay experiments}

Turbulence reduces loss due to sedimentation and enhances nutrient uptake which are good for phytoplankton growth (Prairie et al. 2012; Barton et al. 2014). Higher primary productivity increased the concentrations of total and particulate nutrients (TN, PN, TP, and PP) including Chl $a$, which were higher in $\mathrm{T}$ than $\mathrm{C}$ (Table 2). Additionally, because turbulence enhances the nutrient uptake by the organisms and accelerates the incorporation of dissolved nutrients in water, TDN and DIN concentrations were reduced in $\mathrm{T}$ compared to $\mathrm{C}$ (Table 2). In addition, the synthesis and release of alkaline phosphatase (cleaves the phosphate group in compounds) were further enhanced by turbulence, which accelerated the biogeochemical cycle of phosphorus in the environment (unpublished data). Therefore, we observed that the TDP and SRP concentrations were higher in turbulent set-ups (Table 2).

In the summer of 2007, a massive cyanobacterial bloom made the drinking water plant stop working, leading to a highly publicised drinking water crisis in Wuxi (4 million inhabitants), which forced residents to resort to bottled drinking water (Qin et al. 2010). To control the blooms in Taihu, the government took many measures that mainly focused on controlling and reducing the nutrient ( $\mathrm{N}$ and $\mathrm{P}$ ) inputs (Qin et al. 2010; Xu et al. 2010; Paerl et al. 2011). Artificial mixing by air bubbling was successfully used to prevent the cyanobacterial blooms in Lake Nieuwe Meer, a shallow, hypertrophic lake in the Netherlands (Huisman et al. 2004). Our findings support the possible application of the same method in Taihu to prevent and mitigate the formation of surface blooms of harmful cyanobacteria. However, large-scale, field follow-up experiments may be needed to confirm the findings of the current study.

\section{Conclusion}

By combining field observation data with bioassay experiments, we investigated the impacts of wind wave turbulence on possible shifts in the phytoplankton community composition of Lake Taihu. Observations from the field showed that intense wind waves could be one of the factors preventing the occurrence of harmful cyanobacterial blooms as well as responsible for the shift of the competitive balance by favouring diatoms and green algae. This conclusion explains the low biomass of the cyanobacterium Microcystis at the central lake during summer. The turbulence bioassay experiments also confirmed this observation, which further showed that turbulence could cause shifts in the phytoplankton community composition. We also determined, through the mesocosm bioassay experiments, the critical time before the shift in the phytoplankton community becomes evident, which was approximately 10 days under turbulent conditions. In the long-term (> 10 days), turbulent mixing favoured the dominance of diatom Fragilaria spp., while short-term turbulence would be beneficial to Microcystis. This study further suggests that the duration of wind events and their associated hydrodynamics are key factors for understanding the temporal and spatial changes of phytoplankton communities and the occurrence of harmful cyanobacterial blooms.

\section{Acknowledgements}

We appreciate the very thorough and constructive reviews provided by two anonymous reviewers. This research was supported by the National Science Foundation of China $(41230744,41471021)$ and Water Pollution Control and Management Project (2012ZX07503-002). We thank the Taihu Laboratory for Lake Ecosystem Research (TLLER) for providing the physical, chemical and phytoplankton data.

\section{References}

Arin L, Marrasé C, Maar M, Peters F, Sala1 MM, Alcaraz M (2002) Combined effects of nutrients and small-scale turbulence in a microcosm experiment. I. Dynamics and size distribution of osmotrophic plankton. Auat Microb Ecol 29:51-61

Barton AD, Ward BA, Williams RG, Follows MJ (2014) The impact of fine-scale turbulence on phytoplankton community structure. Limnology and Oceanography: Fluids and Environments 4(1):34-49 
Berger WH, Parker FL (1970) Diversity of planktonic foraminifera in deep-sea sediments. Science 168(3937):1345-1347

Cao HS, Kong FX, Luo LC, Sh XL, Yang Z, Zhang XF, Tao Y (2006) Effects of wind and wind-induced waves on vertical phytoplankton distribution and surface blooms of Microcystis aeruginosa in Lake Taihu. J Freshwater Ecol 21(2):231-238

Cardoso LS, Marques DM (2009) Hydrodynamics-driven plankton community in a shallow lake. Aquat Ecol 43(1):73-84

Carrick HJ, Aldridge FJ, Schelske CL (1993) Wind influences phytoplankton biomass and composition in a shallow, productive lake. Limnol Oceanogr 38(6):1179-1192

Clarke RD, Buskey EJ, Marsden KC (2005) Effects of water motion and prey behavior on zooplankton capture by two coral reef fishes. Mar Biol 146(6):1145-1155

Donaghay PL, Osborn TR (1997) Toward a theory of biological-physical control of harmful algal bloom dynamics and impacts. Limnol Ocennogr 42:1283-1296

Estrada M, Berdalet E (1997) Phytoplankton in a turbulent world. Sci Mar 61:125-140

Guadayol Ò, Peters F (2006) Analysis of wind events in a coastal area: a tool for assessing turbulence variability for studies on plankton. Sci Mar 70(1):9-20

Gulati RD, DeMott WR (1997) The role of food quality for zooplankton: remarks on the state-of-the-art, perspectives and priorities. Freshwater Biol 38(3):753-768

G.-Tóth L, Parpala L, Balogh C, Tàtrai I, Baranyai E (2011) Zooplankton community response to enhanced turbulence generated by water-level decrease in Lake Balaton, the largest shallow lake in Central Europe. Limnol Ocennogr 56(6):2211-2222

Härkönen L, Pekcan-Hekim Z, Hellén N, Ojala A, Horppila J (2014) Combined effects of turbulence and different predation regimes on zooplankton in highly colored water-implications for environmental change in Lakes. Plos One 9:e111942

Hu H, Li Y, Wei Y, Zhu H, Chen J, Shi Z (1980) Freshwater algae in China. Shanghai Science and Technology Press, Shanghai (in Chinese)

Huisman J, Sharples J, Stroom JM, Visser PM, Kardinaal WEA, Verspagen JMH, et al. (2004) Changes in turbulent mixing shift competition for light between phytoplankton species. Ecology 85(11):29602970

Hunter PD, Tyler AN, Willby NJ, Gilvear DJ (2008) The spatial dynamics of vertical migration by Microcystis aeruginosa in a eutrophic shallow lake: a case study using high spatial resolution timeseries airborne remote sensing. Limnol Oceanogr 53(6):2391-2406

Kundu PK, Cohen IM (2010) Fluid Mechanics. San Diego Academic Press, California

Li YP, Feng Y, Liu XP, Luo LC, Xu QX (2008) Numerical modeling of waves in Lake Taihu. J Lake Sci 20(1):117-122 (In Chinese)

Moreno-Ostos E, Cruz-Pizarro L, Basanta A, George D (2009) The influence of wind-induced mixing on the vertical distribution of buoyant and sinking phytoplankton species. Aquat Ecol 43(2):271-284

Oliver RL (1994) Floating and sinking in gas-vacuolate cyanobacteria. J Phycol 30:161-173

Paerl HW, Xu H, McCarthy MJ, Zhu G, Qin B, Li Y, Gardner WS (2011) Controlling harmful cyanobacterial blooms in a hyper-eutrophic lake (Lake Taihu, China): the need for a dual nutrient (N \& P) management strategy. Water Res 45:1973-1983

Pápista É, Ács É, Böddi B (2002) Chlorophyll-a determination with ethanol-a critical test. Hydroiologia 485:191-198

Pekcan-Hekim Z, Joensuu L, Horppila J (2013) Predation by a visual planktivore perch (Perca fluviatilis) in a turbulent and turbid environment. Can J Fish Aqarat Sci 70(6):854-859

Peters F, Marrasé C (2000) Effects of turbulence on plankton: an overview of experimental evidence and some theoretical considerations. Mar Ecol Prog Ser 205:291-306

Peters F, Redondo JM (1997) Turbulence generation and measurement: application to studies on plankton. Sci Mar 61:205-228 
Prairie JC, Sutherland KR, Nickols KJ, Kaltenberg AM (2012) Biophysical interactions in the plankton: a cross-scale review. Limnol Oceanogr 2(1):121-145

Qin, BQ, Xu PZ, Wu QL, Luo LC, Zhang YL (2007) Environmental issues of Lake Taihu, China. Hydrobiologia 581(1):3-14

Qin, BQ, Zhu GW, Gao G, Zhang YL, Li W, Paerl HW, Carmichael WW (2010) A drinking water crisis in Lake Taihu, China: linkage to climatic variability and lake management. Environ Manage 45(1):105112

Romero E, Peters F, Marrasé C (2012) Dynamic forcing of coastal plankton by nutrient imbalances and match-mismatch between nutrients and turbulence. Mar Ecol Prog Ser 464:69-87

Ruiz J, Macias D, Peters F (2004) Turbulence increases the average settling velocity of phytoplankton cells. Proc Natl Acad Sci USA 101(51):17720-17724

Sanford LP (1997) Turbulent mixing in experimental ecosystem studies. Mar Ecol Prog Ser 161:265-293

Wang P, Shen H, Xie P (2012) Can hydrodynamics change phosphorus strategies of diatoms? —nutrient levels and diatom blooms in lotic and lentic ecosystems. Microb Ecol 63(2):369-382

Wilson AE, Samelle O, Tillmanns AR (2006) Effects of cyanobacterial toxicity and morphology on the population growth of freshwater zooplankton: meta-analyses of laboratory experiments. Limnol Oceanogr 51(4):1915-1924

Wong KTM, Lee JHW, Hodgkiss IJ (2007) A simple model for forecast of coastal algal blooms. Estuar Coast Shelf S 74:175-196

Wu T, Qin B, Zhu G, Luo L, Ding Y, Bian G (2013) Dynamics of cyanobacterial bloom formation during short-term hydrodynamic fluctuation in a large shallow, eutrophic, and wind-exposed Lake Taihu, China. Environ Sci Pollut Res 20(12):8546-8556

Wu X, Kong F, Chen Y, Qian X, Zhang L, Yu Y, Zhang M, Xing P (2010) Horizontal distribution and transport processes of bloom-forming Microcystis in a large shallow lake (Taihu, China). Limnologica 40(1):8-15

Xu H, Paerl HW, Qin BQ, Zhu GW, Gao G (2010) Nitrogen and phosphorus inputs control phytoplankton growth in eutrophic Lake Taihu, China. Limnol Oceanogr 55(1):420-432

Zhu GW, Qin BQ, Gao G, Zhang L, Luo LC, Zhang YL (2007) Effects of hydrodynamics on phosphorus concentrations in water of Lake Taihu, a large, shallow, eutrophic lake of China. Hydrobiologia 581(1):53-61

Zhu MY, Paerl HW, Zhu GW (2014) The role of tropical cyclones in stimulating cyanobacterial (Microcystis spp.) blooms in hypertrophic Lake Taihu, China. Harmful Algae 39:310-321

Zohary T (1985) Hyperscums of the cyanobacterium Microcystis aeruginosa in a hypertrophic lake (Hartbeespoort Dam, South Africa). J Plankton Res 7(3):399-409 